\title{
Microbiological and physico-chemical characteristics of stored tsire-suya, a roasted meat product
}

\author{
Roseline Ekiomado UZEH * , Modupeola Olamide AKINYEMI and \\ Chukwudi Christian NDUAGUBA \\ Department of Microbiology, University of Lagos, Akoka, Lagos, Nigeria. \\ *Corresponding author, E-mail: roseline_uzeh@yahoo.com, Tel: +2348051217750
}

\begin{abstract}
The physico-chemical and microbiological characteristics of tsire-suya, a roasted meat product, stored at varying temperatures $\left(4^{\circ} \mathrm{C}, 28{ }^{\circ} \mathrm{C}, 40{ }^{\circ} \mathrm{C}, 50{ }^{\circ} \mathrm{C}\right.$, and $\left.60{ }^{\circ} \mathrm{C}\right)$ for 5 days were studied. The bacteria isolated include Bacillus subtilis, B. brevis, B. megaterium, Pseudomonas aeruginosa, Enterobacter aerogenes, Staphylococcus aureus, S. albus, Klebsiella sp, Acinetobacter mullei and Corynebacterium sp. The fungal isolates include Saccharomyces cerevisiae, Candida spp, Rhodotorula sp, Aspergillus niger, A. Fumigatus, Fusarium moniliforme, and Penicillium sp. Only Bacillus subtilis and B. megaterium, were isolated from tsiresuya stored at $50{ }^{\circ} \mathrm{C}$ and at $60{ }^{\circ} \mathrm{C}$, and there were no physical signs of spoilage, unlike samples stored at $4{ }^{\circ} \mathrm{C}$ and $28{ }^{\circ} \mathrm{C}$ on which there was discolouration and production of off-odour on the $4^{\text {th }}$ day and $2^{\text {nd }}$ day respectively, and slime production on the $4^{\text {th }}$ day in samples stored at $28{ }^{\circ} \mathrm{C}$ in addition to isolation of spoilage organisms like Pseudomonas and even pathogenic organisms like $S$. aureus. The microbial count decreased at all storage temperatures except at $28{ }^{\circ} \mathrm{C}$ where there was an increase. However, $50{ }^{\circ} \mathrm{C}$ and $60{ }^{\circ} \mathrm{C}$ were good for safe storage of tsire-suya as no spoilage organisms or pathogenic organisms were isolated at these temperatures. But we will recommend storage at $50{ }^{\circ} \mathrm{C}$ because samples here were not as hard as those stored at $60{ }^{\circ} \mathrm{C}$. The usual practice of storing tsire-suya at $28^{\circ} \mathrm{C}$ should be discouraged as the product is not safe and it is of poor quality when stored at this temperature. The development of the suya industry would be greatly enhanced by this study on time / temperature limits related to storing of tsire-suya.

(c) 2012 International Formulae Group. All rights reserved.
\end{abstract}

Keywords: Physico-chemical, bacteria, fungi, temperature, tsire-suya.

\section{INTRODUCTION}

Meat can be processed and consumed in different forms such as boiled, stewed, fried, roasted, smoked and other ready to eat meat products, in all of these; heat treatment is given to the meat which alters its characteristics (Nwabueze and Nwabueze, 2001). Tsire-suya also known as "sticked meat" is an important ready-to-eat meat product consumed by a high population of
Nigerians. It is a popular, nutritious item of human diet containing amino acids needed to build and maintain body tissues (Donald, 1994). Traditionally, tsire-suya is prepared by roasting the meat on fire after sticking and addition of ingredients like table salt, pepper, groundnut and groundnut oil. The unwholesome attitude of some producers and hawkers of the meat product which include processing in dirty environments, inadequate 
covering during sales and working with unclean hands bring about contamination by microorganisms of different species. Uzeh et al. (2006) reported that their isolation of Escherichia coli from tsire-suya could be as a result of poor hygiene by the producers. They also explained that coliform count of $1 \times 10^{2}-$ $42 \times 10^{2} \mathrm{cfu} / \mathrm{g}$ obtained by them calls for concern. It has been observed that most readyto-eat meat products and meat are often displayed in Nigerian markets under poor hygienic conditions and hence contaminated by various microorganisms (Faparusi, 1981). Usually tsire-suya is not exhausted in a day which therefore necessitates storage overnight at ambient temperature or hawking of the product later in the night. The need for wholesome meat products cannot be overemphasized because of the ill effects or disease conditions emanating from contaminated meat products.

The objectives of this research therefore are to; isolate microorganisms present in stored tsire-suya, determine the microbial populations and assess the physicochemical characteristics of tsire-suya stored at different temperatures and probably suggest the most suitable storage temperature in line with the safety and quality of this meat product.

\section{MATERIALS AND METHODS \\ Collection of samples}

Samples of tsire-suya were collected from Surulere, Lagos. Samples were collected in sterilized bottles and taken to the laboratory with minimum delay.

\section{Storage of samples}

The tsire-suya samples were stored at different temperatures of $4{ }^{\circ} \mathrm{C}$ in the refrigerator, $28{ }^{\circ} \mathrm{C}$ (room temperature), $40{ }^{\circ} \mathrm{C}$, $50{ }^{\circ} \mathrm{C}$ and $60{ }^{\circ} \mathrm{C}$ in the oven for 5 days. Samples were analyzed for physico-chemical and microbiological characteristics every day.

\section{Physico-chemical analysis Physical characteristics}

The stored samples were monitored for physical changes such as slime production, development of off-odour, and discolouration.

\section{Determination of $\mathrm{pH}$}

From each sample $10 \mathrm{~g}$ were weighed, suspended in $90 \mathrm{ml}$ of distilled water, shaken vigorously and the $\mathrm{pH}$ determined with a $\mathrm{pH}$ meter.

\section{Determination of moisture content}

From each sample $5 \mathrm{~g}$ were weighed into a dry and pre-weighed dish. The sample was dried in hot air oven at $100{ }^{\circ} \mathrm{C}$ for $4-6 \mathrm{hrs}$. Product moisture was determined in duplicate according to AOAC (1992) method. At regular intervals of 30 mins during the drying operation, samples were taken from the drying product, allowed to cool in a desiccator and weighed. This was repeated until a constant weight was obtained. Moisture was calculated in percentage from the following:

$\%$ moisture $=$ Loss in weight $/$ sample weight $\times 100$

\section{Microbiological analysis of tsire-suya}

From each tsire-suya sample $10 \mathrm{~g}$ were weighed and homogenized in $90 \mathrm{ml}$ of distilled water. Serial dilutions were made. From each dilution $1 \mathrm{ml}$ was plated on nutrient agar, MacConkey agar and potato dextrose agar in duplicates using the spread plate method. Nutrient agar and MacConkey agar plates were incubated at $37^{\circ} \mathrm{C}$ for $24 \mathrm{hrs}$, while the potato dextrose agar plates were incubated at $25{ }^{\circ} \mathrm{C}$ for $72 \mathrm{hrs}$. Developed colonies were counted from plates having between 30 and 300 discrete colonies, and the mean counts were recorded. The different isolates obtained were sub cultured to obtain pure cultures.

\section{Identification of microbial isolates}

The microbial isolates were identified using cultural, morphological, and biochemical characteristics based on standard methods (Talbot, 1971; Buchanan and Gibbons, 1974; Adams and Moss, 2000). Cultural characteristics were as observed on the plates. After Gram staining for bacterial isolates and staining fungal isolates with lacto-phenol blue, morphology was observed under the light microscope- Nikon SE Japan, model number 132757. Biochemical tests done include catalase, oxidase, indole, methyl red,Voges-Proskauer, citrate utilization, urease, starch and gelatin hydrolysis, nitrate reduction, and carbohydrate fermentation. 


\section{Statistical analysis}

There was need to determine if there was any significant difference between the microbial populations in stored tsire -suya each day and throughout the storage period. All analyses were done in triplicate. Results of microbial count were analyzed statistically using analysis of variance (ANOVA) with Prism Graph Pad software. Significance was defined at $\mathrm{P}<0.05$

\section{RESULTS AND DISCUSSION}

During 5days storage period of tsiresuya, the $\mathrm{pH}$ was relatively stable (Figure. 1) but signs of spoilage such as green and black colouration, slime production and off-odour were observed in tsire-suya stored at $4{ }^{\circ} \mathrm{C}$ and $28^{\circ} \mathrm{C}$ at the end of storage. The spoilage signs started appearing on the $4^{\text {th }}$ day and $1^{\text {st }}$ day in tsire-suya stored at $4^{\circ} \mathrm{C}$ and $28^{\circ} \mathrm{C}$ respectively. However, these spoilage signs were not observed in samples stored at $40{ }^{\circ} \mathrm{C}$, $50{ }^{\circ} \mathrm{C}$ and $60{ }^{\circ} \mathrm{C}$. These changes could be as a result of microbial activities since different types of microorganisms were isolated from these samples among which were Pseudomonas sp. and Acinetobacter sp. the organisms which may have played a major role in these changes. Adams and Moss (2000) reported that Pseudomonas and Acinetobacter are major genera associated with spoilage of meat but with Pseudomonas spp. predominating. Uzeh et al. (2006) reported that Pseudomonas aeruginosa was resistant to Afromomum melegueta, Piper quineense and Capsicum fructescens all of which are spices and part of the spices used in preparing tsire-suya. The bacteria isolated from tsire-suya stored at different temperatures include Bacillus subtilis, Micrococcus roseus, Micrococcus luteus, Flavobacterium sp., Pseudomonas putida, Pseudomonas aeruginosa, Enterobacter aerogenes, Staphylococcus aureus,
Alcaligenes faecalis, Klebsiella sp., Staphylococcus albus, Acinetobacter mullei, Bacillus brevis, Corynebacterium sp., Streptococcus sp., Bacillus coagulans, Bacillus megaterium, Bacillus polymyxa, and Bacillus sp. (Table 1). The fungi isolated include Saccharomyces cerevisiae, Candida sp., Rhodotorula sp., Aspergillus niger, Aspergillus fumigatus, Fusarium moniliforme, Fusarium oxysporium, and Penicillium sp. (Table 1). The samples stored in the oven (40 ${ }^{\circ} \mathrm{C}, 50{ }^{\circ} \mathrm{C}$, and $60{ }^{\circ} \mathrm{C}$ ) were hard and dark in colour. At higher storage temperatures and period, tsire-suya lost the highest moisture. Hence the lowest moisture content was recorded on the $5^{\text {th }}$ day at $60{ }^{\circ} \mathrm{C}$ and the highest moisture content during storage was on day 1 , at $4{ }^{\circ} \mathrm{C}$. Generally, the moisture content ranged between $6.88 \%$ and $43.18 \%$ (Figure 2). Tsire-suya stored at $4{ }^{\circ} \mathrm{C}$ and 28 ${ }^{\circ} \mathrm{C}$ had both bacteria and fungi. However, only few bacterial species mostly of the genus Bacillus were isolated from the oven samples but no fungi were isolated. Oven temperatures helped to eliminate most of the microbial isolates present in tsire-suya. Bacillus spp., due to their sporing nature, were able to survive the oven temperatures. The microbial load of tsire-suya decreased all through storage at all storage temperatures except for samples stored at $28{ }^{\circ} \mathrm{C}$ where there was increase in microbial count with the highest count recorded on the $5^{\text {th }}$ day, while the lowest count was obtained from samples stored at 4 ${ }^{\circ} \mathrm{C}$ (Figure 1). Statistical analysis revealed that there was significant difference in mean microbial load of stored tsire-suya at $\mathrm{P}<0.05$. Storage temperature of $28{ }^{\circ} \mathrm{C}$ was the most suitable temperature for most of the microbial isolates, and it is the usual holding or storage temperature for tsire-suya. This should therefore be discouraged among producers of this delicatessen meat product. 
A

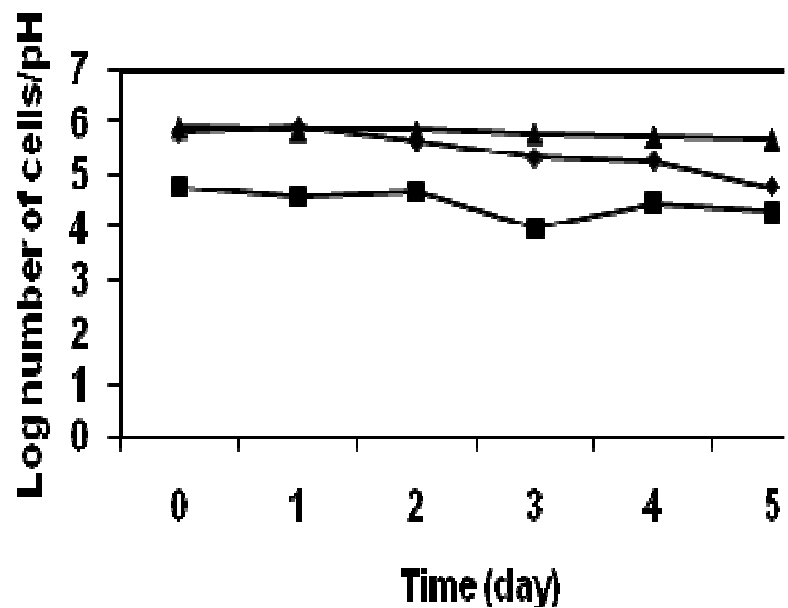

B

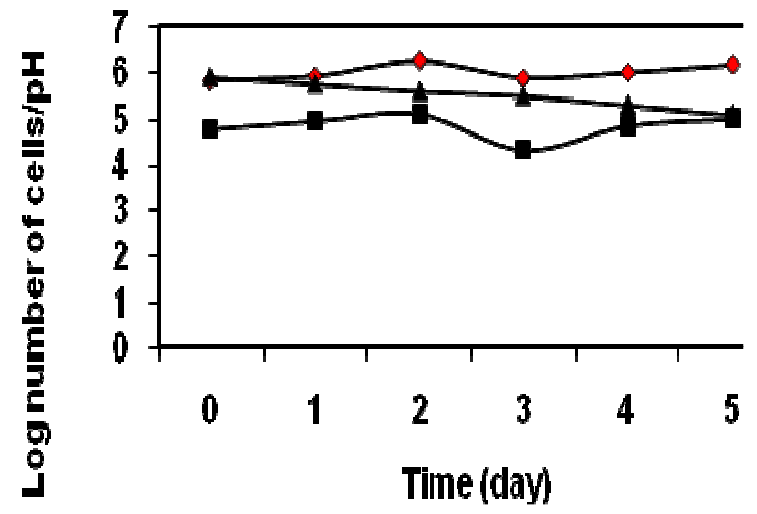

$c$

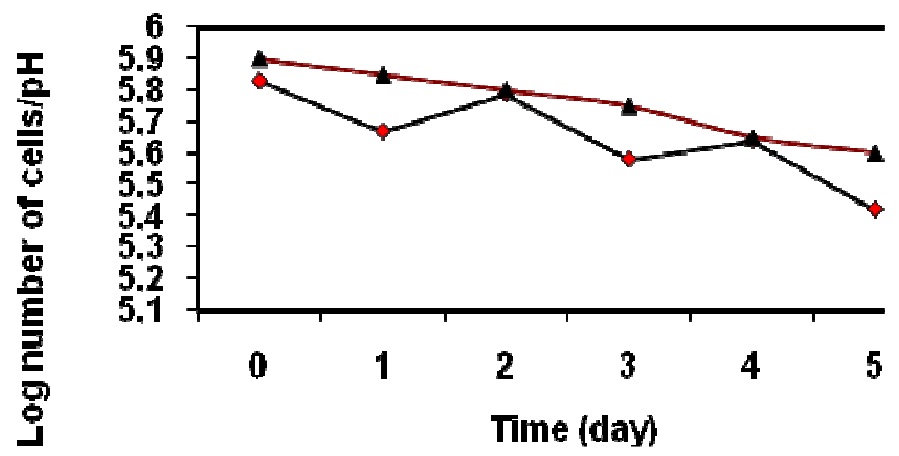


D

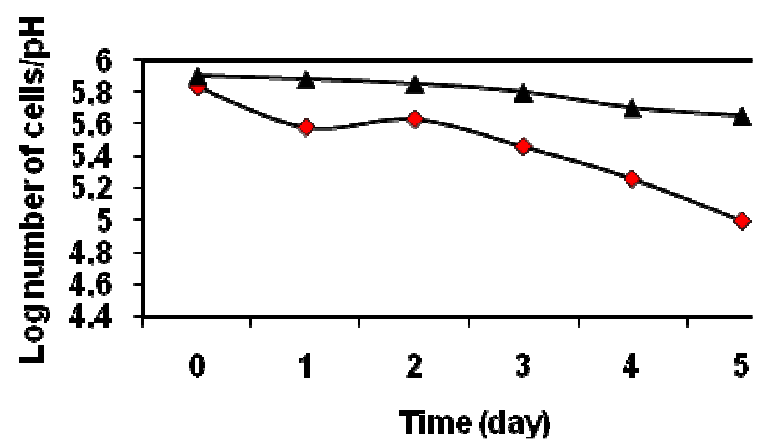

E

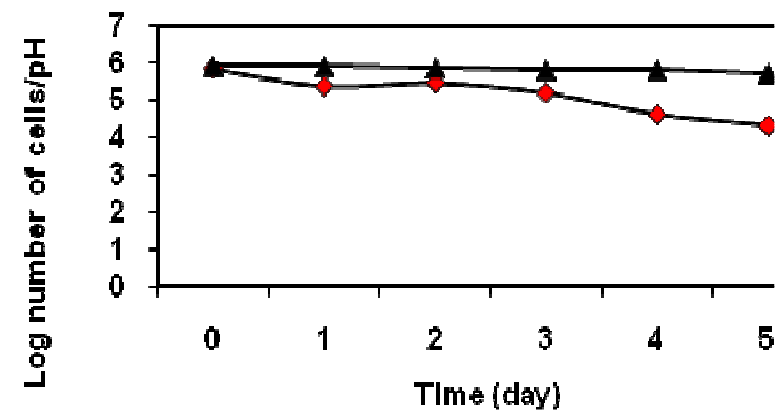

Figure 1: Changes in bacterial count $\downarrow$, fungal count $\mathbf{m}$, and $\mathrm{pH} \boldsymbol{\Delta}$, of tsire-suya during storage at different temperatures $\left(\mathrm{A}=4^{\circ} \mathrm{C}, \mathrm{B}=28^{\circ} \mathrm{C}, \mathrm{C}=40^{\circ} \mathrm{C}, \mathrm{D}=50^{\circ} \mathrm{C}, \mathrm{E}=60^{\circ} \mathrm{C}\right)$.

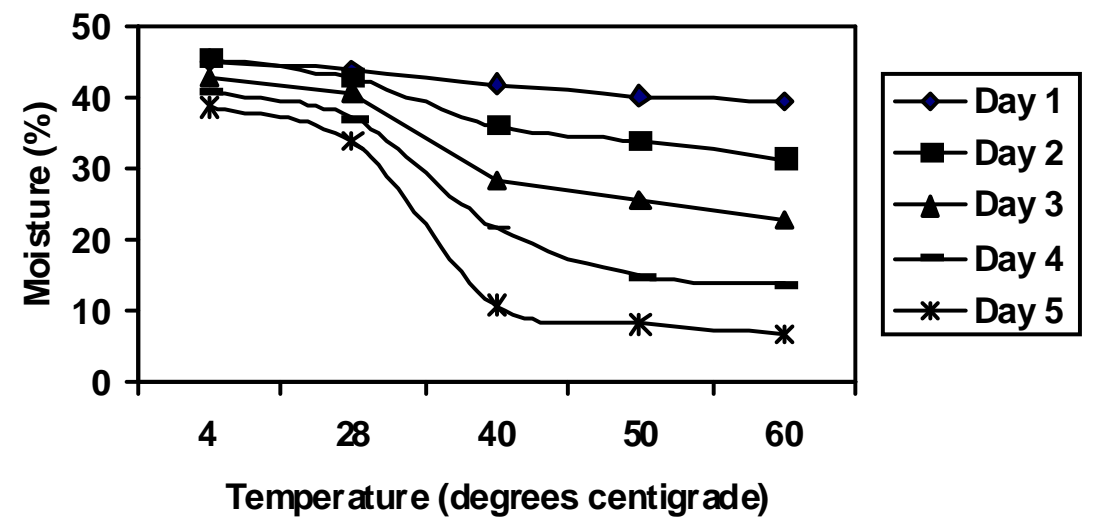

Figure 2: Changes in moisture content of tsire-suya during storage at different temperatures. 
Table 1: Microorganisms isolated from tsire-suya stored at different temperatures.

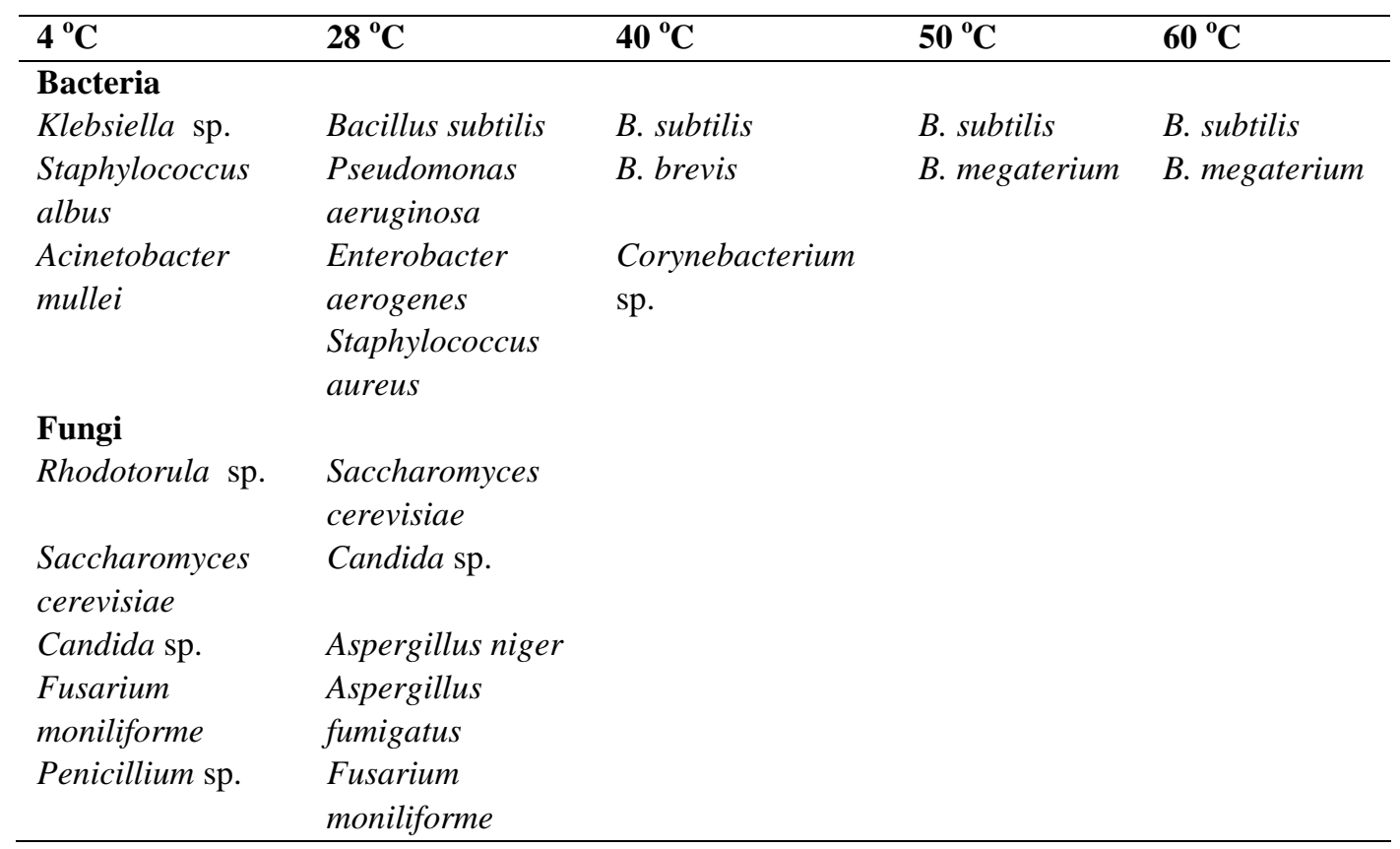

\section{Conclusion}

Both physical changes and results of microbiological analysis can be used to determine tsire-suya that is safe. We will like to recommend storage at $50{ }^{\circ} \mathrm{C}$ for tsire-suya. At this temperature only Bacillus coagulans and $B$. megaterium were isolated and the meat was not as hard as those stored at $60{ }^{\circ} \mathrm{C}$. They are not food pathogens or spoilage organisms associated with meat or meat products. Although the lowest microbial count was obtained from samples stored at $4{ }^{\circ} \mathrm{C}$, pathogenic and spoilage organisms were isolated and this makes tsire-suya not very safe at this storage temperature especially after 3 days.

\section{REFERENCES}

Adams MR, Moss MO. 2000. Food Microbiology $\left(2^{\text {nd }}\right.$ edn). The Royal Society of Chemistry: Cambridge, UK; $447 \mathrm{pp}$.

AOAC. 1992. Official Methods of Analysis $\left(17^{\text {th }}\right.$ edn). Association of Official Analytical Chemists: Washington D.C.
Buchanan RE, Gibbons NE. 1974. Bergey's Manual of Determinative Bacteriology $\left(8^{\text {th }}\right.$ edn). Baltimore Williams and Wilkins Co.

Donald HB. 1994. Meat Extract in World Book of Encyclopedia. World Book Incorporated: Chicago; 350-351.

Faparusi SI. 1981. Identification of microorganisms from Khundi, a smoked meat. J. Food Tech., 44: 581-582.

Nwabueze TU, Nwabueze JC. 2001. Effect of heat source on consumer acceptability and microbiological quality of beef suya. Nig. Food J., 8: 65-69.

Talbot PHR. 1971. Principles of Fungal Taxonomy. Macmillan Press: London; 274.

Uzeh RE, Ohenhen RE, Adeniji OO. 2006. Bacterial contamination of tsire-suya, a Nigerian meat product. Pakist. J. Nutrit., 5(5): 458-460. 